\title{
THE WHITE MAN'S DEBT TO THE NEGRO
}

\author{
By L. H. Hammond, \\ Paine College, Auguata, Ga.
}

We hear the phrase with increasing frequency - "the white man's debt to the Negro;"' but there is no debt white people owe to Negroes on the ground of race. As a descendant of slave-owners, a long-time friend of the Negro, and a lover of my own people, Southern problems are for me both an inheritance and an environment; and I believe both the North and the South have obscured and magnified the task of Negro uplift by continually talking and thinking about it in terms of race. If we would see life sanely, we must see it whole. No race can be understood when regarded as a detached, and consequently anomalous, fragment, cut off from its wide human relations. Races are human first and racial afterwards. Differences go deep, and abide; but likenesses go deeper yet: the most radical evolutionist and the most ultra-orthodox Christian must agree on that point.

There are just two things in the so-called Negro problem which are really questions of race. One of them is the desire of the better classes of both races to keep whites and blacks racially, and therefore socially, distinct. This is expensive, especially in the matter of separate public schools; but no wise man, in either race, objects to that. In such a case, however, both justice and statesmanship require that school provision be made, not according to a man's ability to support the schools but according to the children's needs. This standard is far from being attained in the South, or in many other sections; yet our best men see its wisdom, and we do move toward it, though slowly and haltingly.

The other purely racial ingredient of the "Negro" problem is prejudice; and it is not confined to either race. Yet after all, though racial and local in its manifestations, as race prejudice must always be, it is as wide as humanity and as old as time. It cannot be charged upon the South alone, nor are its manifestations in the South, in any respect, peculiar to Southern whites or Southern blacks; 
they are peculiar to that stage of intellectual and moral growth which those manifesting the prejudice have attained. And, knowing this, one may regard it, not without sorrow, but without bitterness, and with hope. It is a stage of life, and it will pass.

With these two exceptions all that we white Americans, North and South, have so long known as the Negro problem is not Negro nor racial, but human; and the sooner we all recognize this fact the sconer our sectional and racial prejudices and animosities will give place to mutual sympathy and coöperation. There can be, in the nature of things, no successful sectional appeal between North and South, nor successful racial appeal from black to white, or vice versa; a successful appeal must be made from a common standingground, and that we find, not in our differences, but in our common humanity.

Our Negro problem is, with the exceptions noted, our fragment of the world-problem of the privileged and the unprivileged, of the strong and the weak, dwelling side by side. It is human, and economic. We say, here in the South, that the mass of the Negroes are thriftless and unreliable; that their homes are a menace to the health of the community; and that they largely furnish our supply of criminals and paupers. And most of us believe that all this is the natural result, not of the Negro's economic status, but of the Negro's being Negro.

There is truth in the indictment; yet it is by no means so largely true as many of us believe. Take a single instance: the census of 1910 shows the value of Negro-owned farm lands in the South to be $\$ 272,922,238$, a gain of over 150 per cent for the decade. The same decade shows a decrease in Negro illiteracy from 48.1 per cent in 1900 to 33.4 per cent in 1910 . These figures prove that the race is advancing rapidly, no matter how much ignorance, incompetence and criminality remain for future elimination. They also prove, lynching and other barbarities to the contrary notwithstanding, that Southern whites, as a whole, are not as bad neighbors for Southern blacks as some of our Northern brethren fear.

A main reason for disregarding, in our estimates of Negro life, the extraordinary progress of a large and growing section of the race, and for our fixing our attention almost entirely upon its less desirable members is that the latter are the Negroes most prominent in our own lives. As the Negro gains in culture, in efficiency, in 
his struggle for a competence, he withdraws into a world of his own, 2 world which lies all about us white folk, yet whose existence we rarely suspect. The inefficients of the race, the handicapped, the unambitious, the physically and morally degenerate-all these remain in that economic morass which we regard as purely racial; and from them we draw the bulk of our supply of unskilled laborers and servants. From this class, too, we fill our jails; and to many of us it is all the class there is. As fast as a man rises out of it he disappears from our field of vision.

I have been impressed increasingly by these facts since my husband and I have laid aside other things and come to live at a school for the higher education of Negroes. In our many previous years of effort to aid the race we had become aware of this withdrawn world, of course; but it remained remote, intangible, save for brief, bewildering glimpses. It is not yet an open world; but since we have taken this public and decisive stand of sympathy we pass the threshold, and come upon that deeper life which aspires in the breasts of those who carry in their own hearts the sorrows and burdens of a race. One must be struck with a sense of the sacrificial instinct of this class. It is with Negroes as with other races: under pressure of misfortune or of calamity a race or a nation, like an individual, sinks down to the sources of life, and rises to wider vision; brotherhood becomes real to them. The Negro who has risen to higher intellectual and industrial levels and who does not realize his debt of service to the less fortunate of his race is rather the exception than the rule.

But the mass of the Negroes are still in the economic morass; and we of the South do not yet realize that conditions such as it furnishes produce exactly the same results in men of all races, the world around. In a population racially heterogeneous, like that of New York or Chicago, or in one racially homogeneous like that of London or Rome, or in a bi-racial population like our own, the people who live on the edge of want, or over it, furnish nearly the whole of the world's criminal supply. Insufficient food, housing conditions incompatible with health or decency, a childhood spent unprotected in the streets - these things produce, not in this race or that, but in humanity, certain definite results: ill-nourished bodies, vacant and vicious minds, a craving for stimulants, lack of energy, weak wills, unreliability in every relation of life. French slums 
breed French folks like that, Chinese slums breed such Chinamen, English slums Englishmen of the same kind, and Negro slums such Negroes.

When we see this, approaching our "Negro" problem by worldpaths, grasping it in its world-relations, we will begin to do what the privileged classes are learning to do elsewhere-to widen the bounds of justice, to open the door of opportunity for all, to give our slum-dwellers a living, human chance.

It is not for a moment claimed that when they have a human chance slum dwellers of many races and of diverse inheritances will be all of one pattern. It is only in the depths of undevelopment that differences disappear. In the lowest forms of life even animal and vegetable seem one; but as life develops it differentiates. Slumdwellers, when the way of growth is opened for them, come true to type, and will render each their own racial service to the human brotherhood.

Here in the South, as elsewhere, the stability of civilization is to be measured by the condition of the masses of our working people. Men of all nations have been prone to think that enduring national strength can be built up on rottenness; that national and industrial life can be broad-based and firm though it rest on injustice to the poor and the despised, on ignorance, immorality, inefficiency, disease; that the great huddled mass of workers can be safely exploited and then ignored; that a people may defy the fundamental law of human life and prosper. So, from the beginning, have nations fallen; until, at last, men began to learn. In the old world and in the new we are moving slowly, along much-lauded paths of science, to that ignored simplicity of Jesus Christ, whose word of human brotherhood we have forgotten.

Here in the South we are moving too. Some of our best are turning to serve our neediest. In Louisville, Ky., is a man, the son of an Alabama banker, a man of substance and family, who is conducting settlement work for Negroes, serving them in the same ways that other college-bred men and women serve folk of other races in the same economic class elsewhere. One of the International Y. M. C. A. secretaries, a Southern man, has enrolled six thousand young men in our Southern colleges to study the white man's debt to the Negro; and another Southern secretary is following up the work by organizing these young men for social 
service among Negroes. The Southern University Commission on the Negro, an outgrowth of the first Southern Sociological Congress, held a year ago, is composed of men both young and old from every Southern state university, who are agreed as to the duty of the favored race to secure justice and opportunity for the backward one. The Woman's Missionary Council of the Southern Methodist Church, an organization representing over two hundred thousand of our white women, recently adopted a plan for coöperation between their own local societies, some four thousand in number, and the better class of Negroes, for the uplift of the poorer classes, locally, throughout the South. Through their secretary for Negro work efforts in this direction are already being made at several points. The Southern Baptists have still more recently decided to open a theological seminary for Negro preachers. It is to be in connection with their seminary for white preachers, and the same man, one of their most honored leaders, is to be the head of both institutions. The Southern Presbyterians have long had a theological seminary for Negroes, where Southern white college men have taught their darker brothers. In South Carolina white members of the Episcopal church, both men and women, are giving their personal service to the Negroes. The Southern Methodists have for thirty years maintained a school for the higher education of the race where collegebred Southern white men and women have taught from the beginning. The Southern Educational Association has been on record for several years as favoring the teaching of Negro normal students by Southern whites; and the work of a man like the Virginia state superintendent of Negro rural schools is something for both races to be thankful for. Southern club women, too, in more than one state, are showing both by word and deed a spirit of sympathy with the Negro life in their midst. Among the many encouraging and inspiring utterances by both whites and blacks at the recent meeting of the Southern Sociological Congress in Atlanta no single speech summed up the race situation as did that of a young Negro on the closing night.

"I have always known," he said, "that the old Southern white man understood and trusted the old Negro, and that the old Negro understood and trusted the old Southern white man; but before this congress I never dreamed that the young Southern white man and the young Negro could ever understand or trust one another; and 
now I know they can; and that shoulder to shoulder, each in his own place, they can work out together the good of their common country."

In all the congress, no speech won from the white people heartier applause than this. But the white men who spoke, college professors, lawyers, business men, preachers, had their audience with them also, as they called for justice and brotherhood and service in the spirit of Christ.

The millennium is probably far to seek; but vision is coming to our leaders-a vision of human oneness under all racial separateness, of human service fitted to human need. And as the leaders are, the people will be. When even one man sees truth its ultimate triumph is always assured. Whatever may happen in between, the final issue is inevitable.

The educational needs of the Negroes are great. The mass of them, like the mass of every race, must always work with their hands, doing what we call the drudgery of life. They need to learn, as we all do, that drudgery is not in work, but in the worker's habit of mind. We need, not merely in the South, but in America, to approach the German standard in regard to industrial training for the rich and the poor of all races. As we grow more rational ourselves the Negroes will catch the infection, as they have caught from white folk, North and South, an irrational scorn of "common" work. Our public and private schools, especially our normal schools, for both races, need large development in industrial training. We are awaking to this fact, particularly in regard to our white schools; and as they progress along broader lines progress in schools for Negroes will be easier.

The only absolutely untouched need of the Negro, and it is a need most fundamental, most disastrous in its long neglect, is the need for decent, healthful houses for the poorer classes. We are just developing a social consciousness in the South, and it is naturally first aroused by the needs of the poor whites. We know little, as yet, of slum populations elsewhere, and we think of the Negro slum-dweller as a separate fragment of life, unrelated, a law unto himself, creating his slum as a spider spins his web, from within. We build him shacks and charge heavy rents, as landlords of this economic class do the world around. Cheap as the shelter furnished is, it deteriorates so rapidly, through neglect and misuse, that the 
owners of such property, the world over, declare that the high rentals are necessary to save them from actual loss.

We need an experiment-station in Negro housing in the South. Fifty thousand dollars would buy a city block of six acres, and put on four of them eighty well-lighted, three-roomed houses, with water and a toilet in each, and with a tiny garden-spot. Two acres would furnish a playground for the children, otherwise doomed to ruin in the city streets; and there would be money enough left to put up a settlement house providing for a kindergarten, free baths, boys' clubs, industrial classes, a place of recreation for young people whose only present refuge is a low dance-hall or a saloon. At two dollars per room per month, the price paid in my own town by people of this class for houses which are a menace to the whole community, the income from such an investment would pay the salary of a social worker, who would collect the rent on the Octavia Hill plan, and would yet yield 10 per cent gross on the investment, in dollars and cents. In character-building, in the cutting off of our pauper and criminal supply, in convincing our white people that the slum breeds the Negro we find in the slum, the return on the investment would be incalculable.

An experiment like this, worked out to success and advertised through the South, would awaken the interest and win the approval of very many Southern business men who deplore the Negro slum but see no hope of abolishing it. Money would be invested in decent homes for this class as soon as white men saw it could be done without financial loss. Such an experiment station would do more than any other one thing I know of to help the Negroes who most need help; but the money for this initial enterprise will have to come from beyond the South, where these methods have already been successfully tried. That it will come I firmly believe. When things ought to be done they get done, somehow; and this fundamental need is to be met. 